\title{
Selection of effective irrigation practice for optimum yield of tobacco
}

\author{
J. S. Joy*, M. N. Islam, M. Z. Hasan and M. A. Islam \\ Department of Irrigation and Water Management, Bangladesh Agricultural University, Mymensingh-2202, \\ Bangladesh, *E-mail: joydevbauengg@gmail.com
}

\begin{abstract}
This experiment was conducted to evaluate the response of tobacco yield under different irrigation practices and tobacco varieties during November 2012 to April 2013 (Rabi season) at Paharpur village of Kushtia district. The experiment was laid out in Randomized Complete Block Design (RCBD) with three replications. Four treatments were $T_{0}$ (control, no irrigation), $T_{1}$ (traditional practice; $13 \mathrm{~cm}$ irrigation water applied), $T_{2}(10 \mathrm{~cm}$ irrigation water applied) and $T_{3}\left(5 \mathrm{~cm}\right.$ irrigation water applied). Three tobacco varieties were used for the experiment viz. $\mathrm{V}_{1}(\mathrm{NC} 95), \mathrm{V}_{2}(\mathrm{~K}$ 326) and $V_{3}$ (CS 447). All necessary data on yield and yield contributing characters including irrigation were collected from experimental plots. Irrigation treatments showed significant effects on yield and yield contributing characters of tobacco. Results revealed that the highest cured leaf yield $\left(3.83 \mathrm{t} \mathrm{ha}^{-1}\right)$ was obtained in treatment $T_{2}$ followed by $T_{3}$ $\left(3.46 \mathrm{t} \mathrm{ha}^{-1}\right)$ and $\mathrm{T}_{1}\left(3.07 \mathrm{tha}^{-1}\right)$. The highest and lowest yield were obtained as $5.05 \mathrm{t} \mathrm{ha}^{-1}$ and $2.85 \mathrm{th}^{-1}$ for the interactions $T_{2} V_{2}$ and $T_{1} V_{1}$, respectively. Highest water productivity $(63.92 \mathrm{~kg} / \mathrm{ha} / \mathrm{cm})$ was found in treatment $T_{3}$. Among three tobacco varieties, $V_{2}\left(K\right.$ 326) gave highest yield followed by $V_{3}$ (CS 447) and $V_{1}$ (NC 95) as 3.17, 2.38 and $2.22 \mathrm{t} \mathrm{ha}^{-1}$, respectively. Therefore, application of $10 \mathrm{~cm}$ irrigation water on the variety $\mathrm{K} 326$ can be the promising practice for cultivation of tobacco.
\end{abstract}

Keywords: Tobacco, Optimum, Irrigation, Yield, Effective

\section{Introduction}

Tobacco, belongs to the family Solanaceae and genus Nicotiana is grown more or less in all districts of Bangladesh. The genus Nicotiana contains about sixty species, but only Nicotiana tabacum and Nicotiana rustica are commercially important. Its cultivation is concentrated in Rangpur district which roughly accounts for one-half acreage, the other-half being distributed over all districts. Tobacco is an important cash crop of Bangladesh next to jute and sugarcane. In 2008-09 total land used for tobacco cultivation was almost 30000 ha, which yielded 40272 MT. In Kushtia about 19315 acres of land were under tobacco cultivation and annual production was 11625 MT during 2001-02. The area has now expanded to 22241 acres and the corresponding production is 14985 MT (BBS, 2009).

Tobacco, the shallow rooted crop is usually cultivated in winter season when the rainfall is negligible. So, irrigation water is a critical factor for tobacco production in Bangladesh. But the scarcity of irrigation water is increasing day by day as the demand for irrigation is increasing. So efficient management of irrigation water is needed to increase tobacco yield as well as minimize production cost.

Therefore, the present study was undertaken with the following objectives:

i. To determine optimum irrigation requirement for the yield of tobacco.

ii. To evaluate effects of different water management practices on the yield of three selected varieties of tobacco.

\section{Materials and Methods}

\section{Experimental Site and Period}

The experiment was conducted at Paharpur village of Mirpur Upazila in Kushtia district (located at $23.933^{\circ} \mathrm{N}$ latitude and $89.00^{\circ} \mathrm{E}$ longitude at a mean elevation of $27 \mathrm{~m}$ above the sea level) from midNovember 2012 to mid-April 2013 (Fig. 1). The study area falls under High Ganges River Floodplain (FAO-UNDP, 1988). 


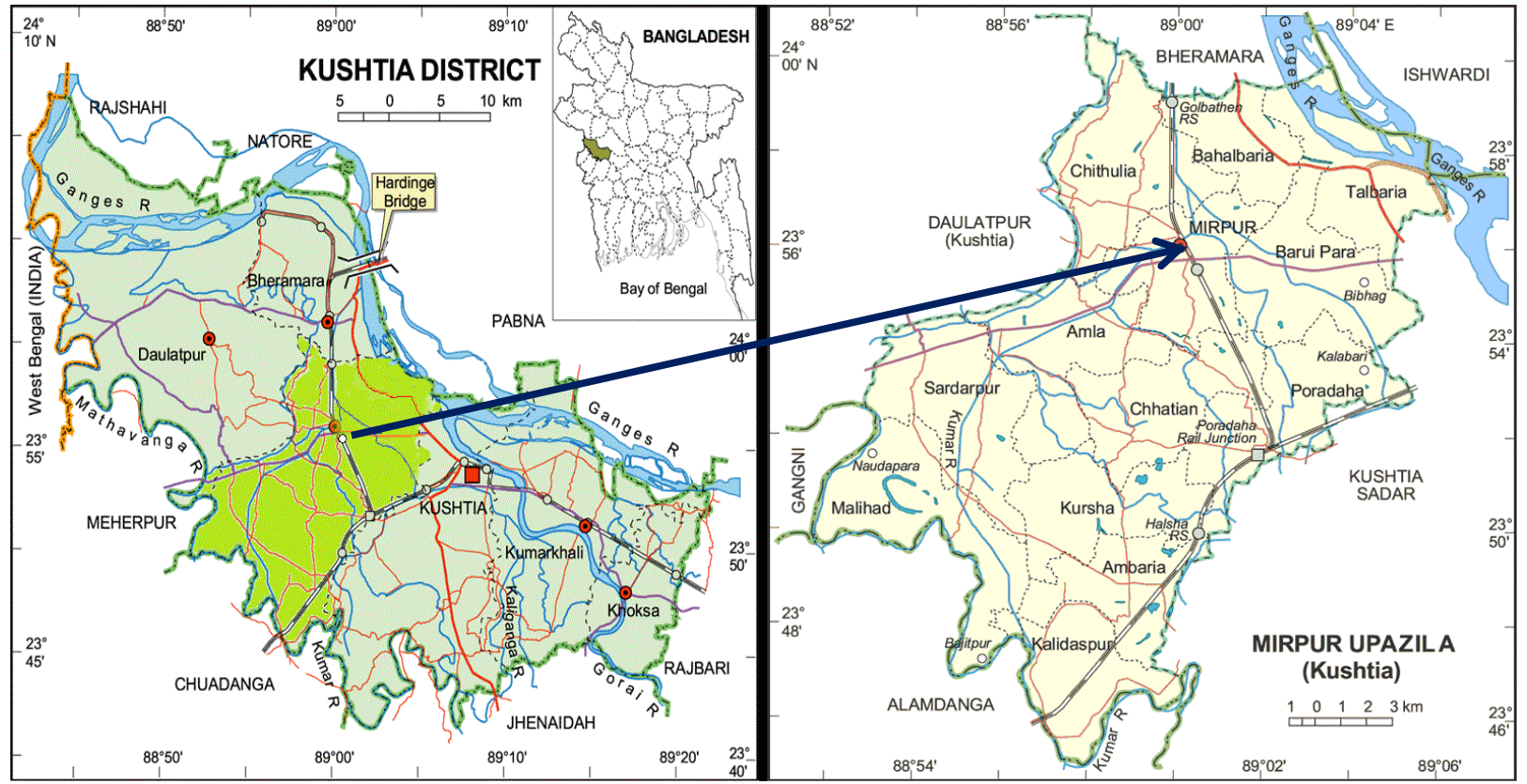

Fig. 1. Location of the experiment

\section{Treatments}

The experiment was laid out in a Randomized Complete Block Design (RCBD) with three replications. There were 36 unit plots of size $3.25 \mathrm{~m} \times 5.70 \mathrm{~m}$. The treatments are shown in Table 1 .

Table 1. Experimental treatment of the plots

\begin{tabular}{|c|l|}
\hline Treatment code & Treatment description \\
\hline$T_{0}$ & Control (no irrigation) \\
\hline$T_{1}$ & Traditional practice (application of $13 \mathrm{~cm}$ irrigation water) \\
\hline$T_{2}$ & Application of $10 \mathrm{~cm}$ irrigation water \\
\hline$T_{3}$ & Application of $5 \mathrm{~cm}$ irrigation water \\
\hline
\end{tabular}

\section{Cultural operations}

Fifty five days old tobacco seedlings were transplanted keeping distance between plant to plant and row to row as 21 and 42 inches, respectively. Intercultural operations viz. weeding, pest control were done when required. Treatment wise irrigation water was applied throughout the cultivation period at an interval of 15 days. On the basis of leaf maturity, harvesting was done at 100, 113 and 126 days after transplantation.

\section{Data Collection}

Randomly five plants were selected from every plot for collection of data. Plant height was measured from ground level to the top of tobacco stack. Number of leaves of plants was counted. Total weight of green leaves was measured freshly after harvest by a balance and cured leaves were weighed after drying.

\section{Water Use Efficiency (WUE)}

Water use efficiency (WUE) was calculated by the following formula (Michael, 1978):

$$
\text { Water Use Efficiency }(\mathrm{kg} / \mathrm{ha} / \mathrm{cm})=\frac{\mathrm{Y}}{\mathrm{WR}}
$$


where, $\mathrm{Y}=$ Cured leaf yield $\left(\mathrm{kg} \mathrm{ha}^{-1}\right), \mathrm{WR}=$ Total amount of water used by the crop $(\mathrm{cm})$.

$$
W R=I R+E R+\sum_{i=0}^{n} \frac{M_{s i}-M_{h i}}{100} A_{1} D_{1}
$$

where, $I R=$ Total irrigation water applied $(\mathrm{cm}), E R=$ Effective rainfall $(\mathrm{cm}), \mathrm{M}_{\mathrm{si}}=$ Moisture content $(\%)$ at sowing time in the $i^{\text {th }}$ layer of soil, $M_{h i}=$ Moisture content (\%) at harvest time in the $i^{\text {th }}$ layer of soil, $A_{i}=$ apparent specific gravity of the $i^{\text {th }}$ layer of soil, $D_{i}=$ depth of the $i^{\text {th }}$ layer of soil $(\mathrm{cm})$.

\section{Statistical Analysis}

The analysis of variance for different crop characters of the treatments was made and the mean differences were adjudged by Duncan's New Multiple Range Test (DMRT) (Gomez \& Gomez, 1984).

\section{Results and Discussion}

\section{Effect of Irrigation treatments}

Mean effects of irrigation treatments on the yield and yield contributing characters of tobacco are shown in Fig. 2.

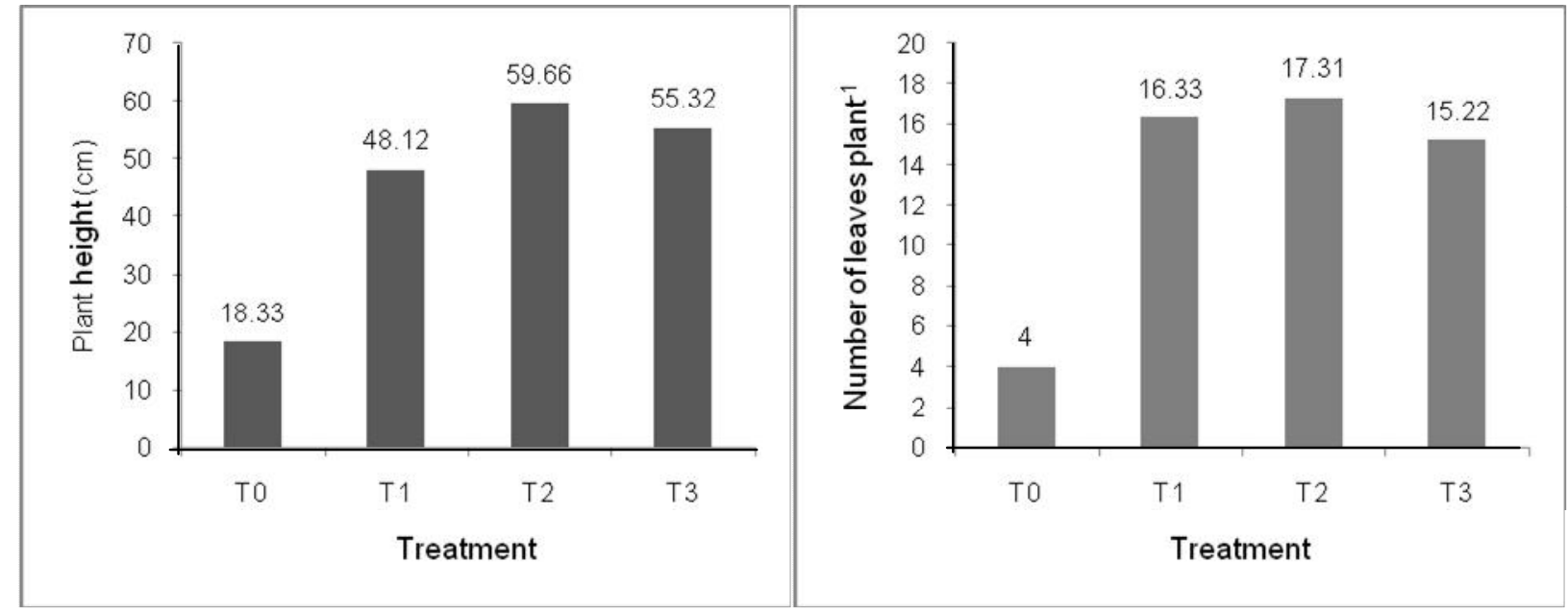

A

B

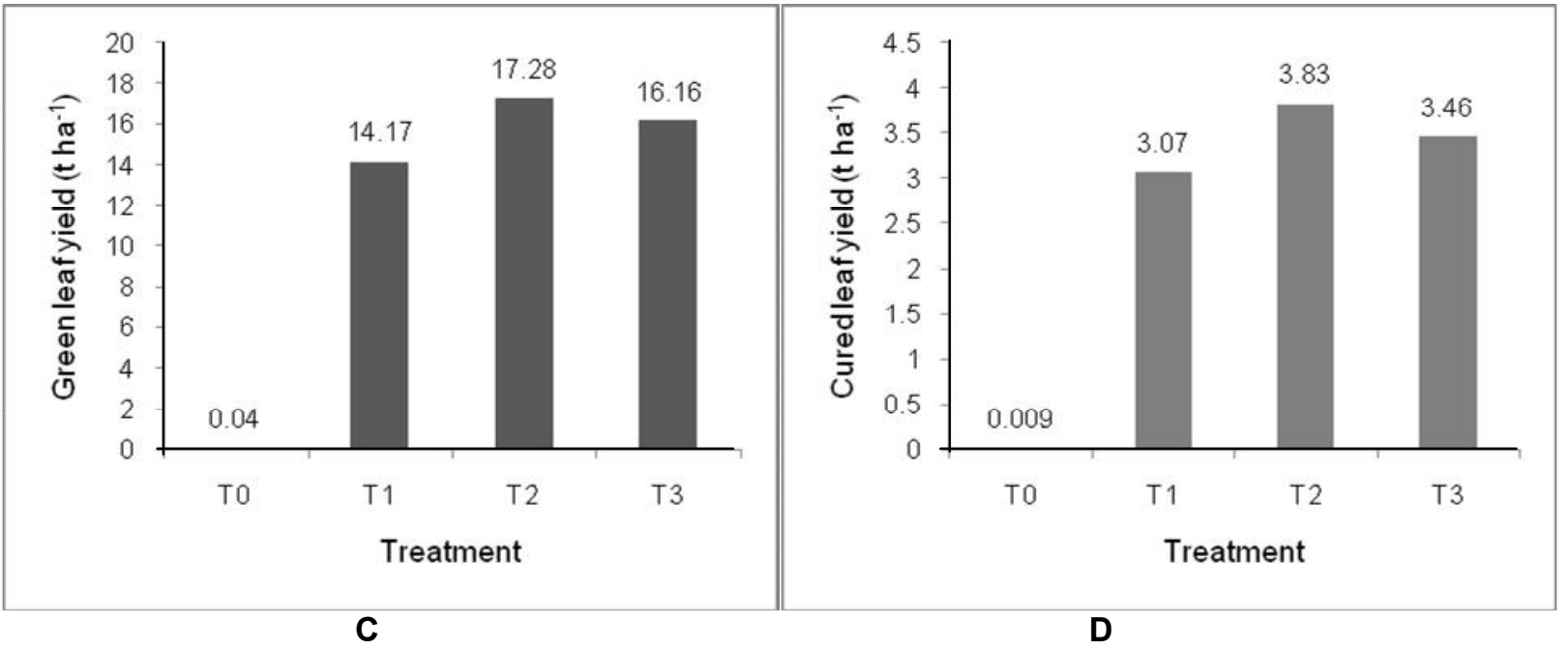

Fig. 2. Mean effects of irrigation treatments on the yield and yield contributing characters of tobacco: (A) Plant height (cm), (B) No. of leaves plant ${ }^{-1},(C)$ Green leaf yield $\left(t \mathrm{th}^{-1}\right)$ and $(\mathrm{D})$ Cured leaf yield $(\mathrm{t}$ $\mathrm{ha}^{-1}$ ) 
Yield and yield contributing characters were significantly influenced by irrigation treatments. $\mathrm{T}_{2}$ (application of $10 \mathrm{~cm}$ irrigation water) produced highest average plant height, number of leaves plant ${ }^{-1}$, green and cured leaf yield.

\section{Effect of Tobacco Varieties}

Mean effects of tobacco varieties used in the experiment are shown in Fig. 3.

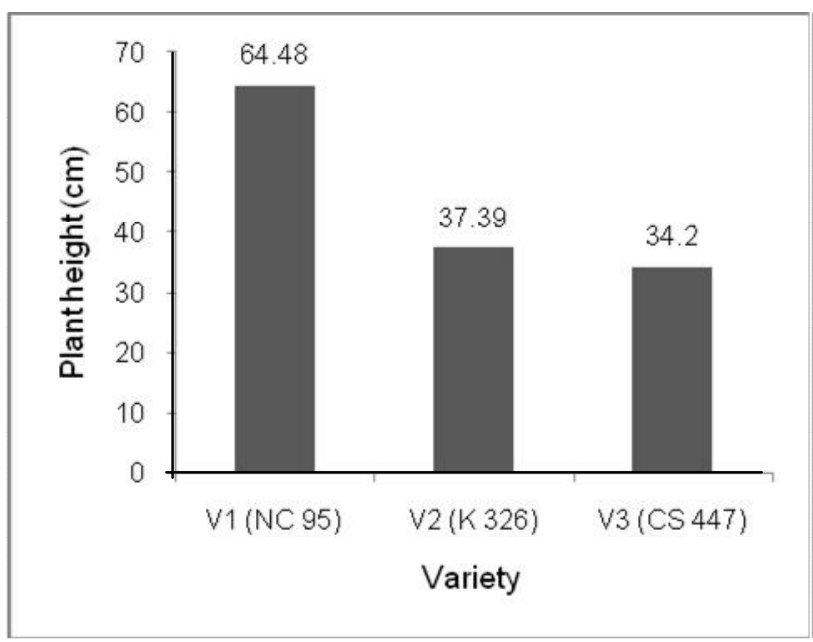

A

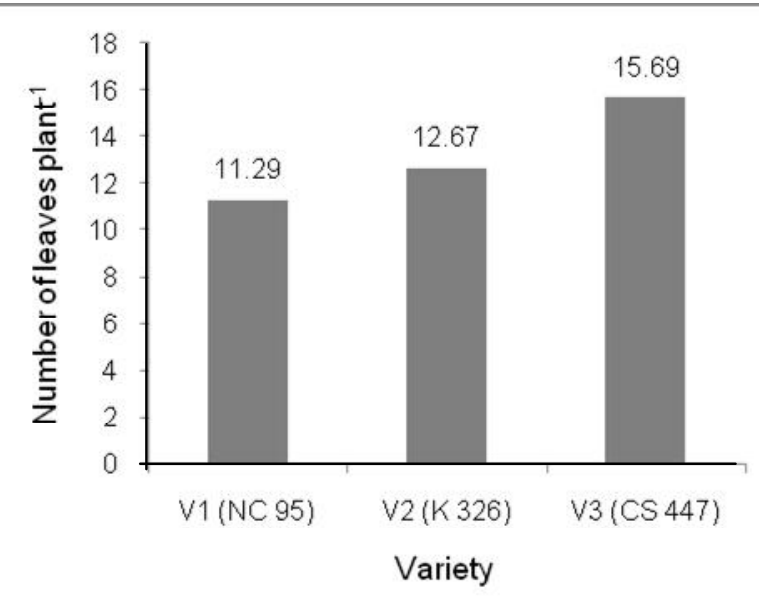

B

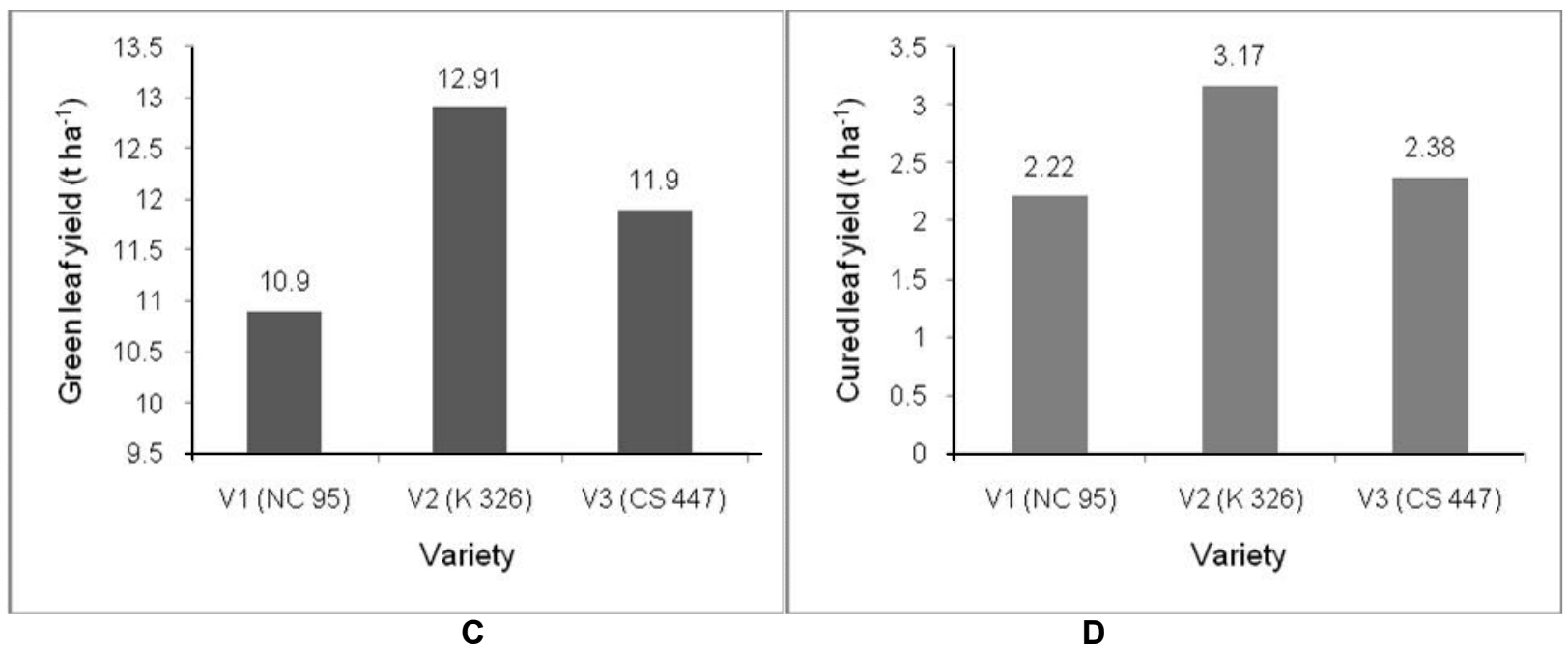

Fig. 3. Mean effects of tobacco varieties on the yield and yield contributing characters of tobacco: (A) Plant height $(\mathrm{cm}),(B)$ No. of leaves plant ${ }^{-1},(C)$ Green leaf yield $\left(\mathrm{t} \mathrm{ha}^{-1}\right)$ and (D) Cured leaf yield $\left(\mathrm{t} \mathrm{ha}^{-1}\right)$

Yield and yield contributing characters were significantly influenced by three tobacco varieties viz. NC 95 , K 326 and CS 447 . The variety NC 95 produced highest average plant height followed by K 326 and CS 447. Average number of leaves plant ${ }^{-1}$ was found highest in CS 447 followed by K 326 and NC 95 . In terms of green and cured leaf yield, highest value was obtained from K 326 . 


\section{Interaction Effect of Treatments and Varieties}

Interaction effects of irrigation treatments and varieties on the yield and yield contributing characters of tobacco are shown in Table 2.

Table 2. Interaction effects of irrigation treatments and varieties on the yield and yield contributing characters of tobacco

\begin{tabular}{|c|l|l|l|l|}
\hline \multirow{2}{*}{ Treatment $\times$ Variety } & \multirow{2}{*}{ Plant height $(\mathrm{cm})$} & \multirow{2}{*}{$\begin{array}{l}\text { No. of leaves } \\
\text { plant }^{-1}\end{array}$} & \multicolumn{2}{|c|}{${\text { Yield }\left(\mathrm{t} \mathrm{ha}^{-1}\right)}^{-1}$} \\
\cline { 4 - 5 } & & $3 \mathrm{~h}$ & Green leaf & Cured leaf \\
\hline $\mathrm{T}_{0} \mathrm{~V}_{1}$ & $20 \mathrm{~g}$ & $4 \mathrm{~g}$ & $0.03 \mathrm{~d}$ & $0.004 \mathrm{~g}$ \\
\hline $\mathrm{T}_{0} \mathrm{~V}_{2}$ & $18 \mathrm{~g}$ & $\mathrm{f}$ & $0.07 \mathrm{~d}$ & $0.01 \mathrm{~g}$ \\
\hline $\mathrm{T}_{0} \mathrm{~V}_{3}$ & $17 \mathrm{~g}$ & $14 \mathrm{e}$ & $0.04 \mathrm{~d}$ & $0.01 \mathrm{~g}$ \\
\hline $\mathrm{T}_{1} \mathrm{~V}_{1}$ & $67.73 \mathrm{c}$ & $16 \mathrm{~d}$ & $13.32 \mathrm{c}$ & $2.85 \mathrm{f}$ \\
\hline $\mathrm{T}_{1} \mathrm{~V}_{2}$ & $38.52 \mathrm{f}$ & $15.35 \mathrm{~b}$ & $3.35 \mathrm{c}$ \\
\hline $\mathrm{T}_{1} \mathrm{~V}_{3}$ & $38.10 \mathrm{f}$ & $19 \mathrm{~b}$ & $13.85 \mathrm{c}$ & $3.01 \mathrm{de}$ \\
\hline $\mathrm{T}_{2} \mathrm{~V}_{1}$ & $88.90 \mathrm{a}$ & $14.50 \mathrm{e}$ & $15.29 \mathrm{~b}$ & $3.08 \mathrm{de}$ \\
\hline $\mathrm{T}_{2} \mathrm{~V}_{2}$ & $47.31 \mathrm{~d}$ & $16.67 \mathrm{~d}$ & $18.50 \mathrm{a}$ & $5.05 \mathrm{a}$ \\
\hline $\mathrm{T}_{2} \mathrm{~V}_{3}$ & $42.76 \mathrm{e}$ & $20.75 \mathrm{a}$ & $18.06 \mathrm{a}$ & $3.34 \mathrm{c}$ \\
\hline $\mathrm{T}_{3} \mathrm{~V}_{1}$ & $81.28 \mathrm{~b}$ & $13.67 \mathrm{e}$ & $14.96 \mathrm{~b}$ & $2.95 \mathrm{ef}$ \\
\hline $\mathrm{T}_{3} \mathrm{~V}_{2}$ & $45.72 \mathrm{de}$ & $14 \mathrm{e}$ & $17.72 \mathrm{a}$ & $4.26 \mathrm{~b}$ \\
\hline $\mathrm{T}_{3} \mathrm{~V}_{3}$ & $38.95 \mathrm{f}$ & $18 \mathrm{c}$ & $15.81 \mathrm{~b}$ & $3.14 \mathrm{~d}$ \\
\hline $\mathrm{LS} \mathrm{D}_{0.05}$ & 3.06 & 0.929 & 1.05 & 0.160 \\
\hline $\mathrm{LS}$ & $* *$ & $* *$ & & \\
\hline $\mathrm{CV}(\%)$ & 3.99 & 4.15 & 5.19 & 3.68 \\
\hline
\end{tabular}

In a column figures with common letter(s) or without letters do not differ significantly as par DMRT;

$\mathrm{V}_{1}=\mathrm{NC} 95, \mathrm{~V}_{2}=\mathrm{K} \mathrm{326}, \mathrm{V}_{3}=\mathrm{CS} 447 ;{ }^{* *}=$ Significant at $1 \%$ level of probability, LS = Level of Significance, LSD = Least Significant Distance

The interaction effect of irrigation treatments and varieties showed significant variation on average plant height, number of leaves plant ${ }^{-1}$, green and cured leaf yield. It was observed that combination of $T_{2}$ with $V_{2}$ produced highest green leaf yield $\left(18.50 \mathrm{tha}^{-1}\right)$ and cured leaf yield $\left(5.05 \mathrm{t} \mathrm{ha}^{-1}\right)$.

\section{Water use and Water Use Efficiency}

Water use and water use efficiency under different irrigation treatments have been shown in Fig. 4.

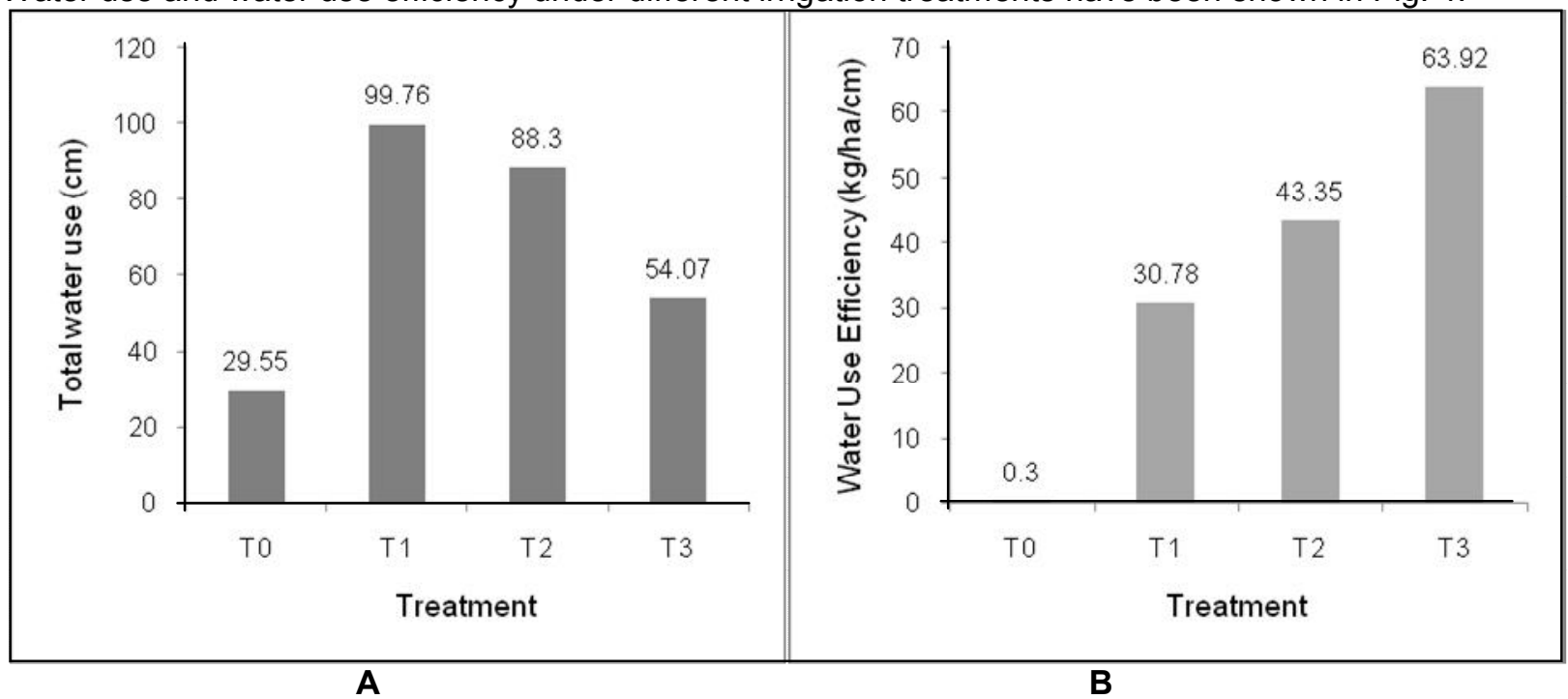

Fig. 4. (A) Total water use and (B) Water Use Efficiency under different irrigation treatments. 
It was observed that total water use was the highest in $T_{1}$ which was traditional practice $(13 \mathrm{~cm}$ the irrigation water) but in term of water use efficiency, $T_{3}$ was found the highest $(63.92 \mathrm{~kg} / \mathrm{ha} / \mathrm{cm})$ the followed by $\mathrm{T}_{2}(43.35 \mathrm{~kg} / \mathrm{ha} / \mathrm{cm})$ where 5 and $10 \mathrm{~cm}$ irrigation water was applied, respectively.

\section{Conclusion}

This study revealed that treatment $T_{2}$ (application of $10 \mathrm{~cm}$ irrigation water) produced the highest average plant height, number of leaves plant ${ }^{-1}$, green and cured leaf yield. In terms of green and cured leaf yield, the highest value was obtained from $\mathrm{K} 326$. The combination of $T_{2}$ with $V_{2}$ produced the highest green leaf yield $\left(18.50 \mathrm{t} \mathrm{ha}^{-1}\right)$ and cured leaf yield $\left(5.05 \mathrm{t} \mathrm{ha}^{-1}\right)$. Although water use efficiency was not found the highest in $\mathrm{T}_{2}$, but considering yields it can be concluded that application of $10 \mathrm{~cm}$ irrigation water on the variety $\mathrm{K} 326$ can be the promising practice for cultivation of tobacco.

\section{References}

BBS, 2009. Statistical Year Book of Bangladesh, Bangladesh Bureau of Statistics, Statistics Division, Ministry of Planning, Government of the people's Republic of Bangladesh. p. 129.

FAO-UNDP. 1988. Production Yearbook, Food and Agricultural Organization of the United Nations, Rome, Italy. 57: 76-77.

Gomez, K.A. and Gomez, A.A. 1984. Statistical procedures of Agricultural Research, $2^{\text {nd }}$ edition, John Wiley and Sons. Inc., New York.

Michael, A.M. 1978. Irrigation: Theory and Practice, $1^{\text {st }}$ edition, Vikas Publishing House Pvt. Ltd., 576, Masjid road, Jangpura, New Delhi. pp. 501-551. 